\title{
Penerapan Metode Iqro Sebagai Kemampuan Dasar Membaca Al-Qur'an Di TK Hiama Kids
}

\author{
Zulfitria $^{1)}$, Zainal Arif ${ }^{2}$, \\ ${ }^{1}$ Universitas Muhammadiyah Jakarta \\ ${ }^{2}$ Universitas Muhammadiyah Tangerang \\ email: fzulfitria@yahoo.com
}

\begin{abstract}
Abstrak:
Mengajarkan membaca Alquran pada anak usia dini bukan hal mudah, karena selain memerlukan pengetahuan seorang pendidik juga harus mengetahui metode yang dapat dipakai dalam proses pembelajaran. Penelitian ini bertujuan untuk mengetahui penerapan metode iqro sebagai kemampun dasar membaca Al-Quran di TK HIAMA kids. Penelitian ini berupa penelitian kualitatif. Alat pengumpul datanya berupa pedoman wawancara, observasi dan dokumentasi untuk memperoleh data dan menganalisisnya bagaimana penerapan metode Iqro sebagai kemampuan dasar membaca Al-Qur' an di TK HIAMA Kids. Dari hasil penelitian, adanya peningkatan kemampuan membaca Al-Qur'an melalui metode Iqro di TK HIAMA kids, hal ini menunjukkan bahwa sebagian besar siswa TK HIAMA Kids senang belajar Al-Quran dengan menggunakan metode Iqro sehingga mampu membaca Al-Qur'an dengan lancar dan tajwid yang baik.
\end{abstract}

Kata Kunci: penerapan, metode Iqro, Al-Quran

\begin{abstract}
:
Teaching reading the Koran in early childhood is not easy, because in addition to requiring knowledge, an educator must also know the methods that can be used in the learning process. This study aims to determine the application of the iqro method as the basic ability to read the Koran in TK HIAMA kids. This research is in the form of qualitative research. The data collection tool is in the form of interview, observation and dol guidelines documentation to obtain data and analyze how the application of the Iqro method as a basic ability to read the Qur'an at TK HIAMA Kids. From the results of the study, there was an increase in the ability to read the Qur'an through the Iqro method in TK HIAMA kids, this shows that most HIAMA Kids kindergarten students love to learn the Koran by using the Iqro method so that they are able to read the Qur'an smoothly and good tajwid.
\end{abstract}

Keywords: application, Iqro method, Al-Quran

\section{PENDAHULUAN}

Pendidikan hendaklah dilakukan

sejak dini dapat dilakukan di dalam keluarga, sekolah, maupun masyarakat. Berbagai hasil para pakar kejiwaan mengatakan bahwa perawatan anak usia 
dini dalam keluarga mempunyai pengaruh besar di kemudian hari. Pendidikan anak usia dini adalah suatu proses pembinaan dan perkembangan jasmani dan rohani agar anak memiliki kesiapan rangsangan dalam memasuki pendidikan lebih lanjut. (Boediono dkk, 2003). Pendidikan merupakan bimbingan atau pimpinan secara sadar oleh seorang guru terhadap perkembangan jasmani dan rohani anak didik menuju terbentuknya kepribadian utama. (Marimba, 2009)

Perkembangan teknologi dan informasi dalam era globalisasi membawa pengaruh perubahan yang signifikan dalam membentuk watak dan kepribadian seseorang, baik pengaruh positif maupun pengaruh negatif kepada anak khususnya pada anak usia dini yang lebih cepat mencontoh.

Dunia pendidikan mempunyai tantangan yang sangat berat karena dituntut untuk dapat melahirkan manusia-manusia yang tidak hanya mampu menguasai teknologi dan informasi agar dapat bersaing di dunia internasional akan tetapi juga menjadi manusia yang beradab.

Kemajuan peradaban suatu bangsa pada hakikatnya dimulai dari pengembangan di bidang pendidikan. Hal ini ditandai dengan turunnya firman Allah SWT yang pertama dalam Al-Qur' an surat Al-'Alaq (96:1-5) yaitu:

Bacalah dengan (menyebut) nama Tuhan-mu yang menciptakan, Dia telah menciptakan manusia dari segumpal darah. Bacalah, dan Tuhanmu-lah Yang Mahamulia, Yang mengajar (manusia) dengan pena, Dia mengajar manusia apa yang tidak diketahuinya (Depag, 2007).

Allah SWT telah mengisyaratkan kepada seluruh umat manusia untuk banyak belajar berbagai hal untuk dapat membaca tanda-tanda kekuasaan Allah SWT yang ada dalam kehidupan, karena dengan membaca tentunya banyak menemukan hal-hal baru yang sangat bermanfaat sebagai bekal hidup di dunia dan di akhirat. (Zulfitria, 2017)

Pendidikan memegang peranan yang sangat penting dalam peningkatan kualitas sumber daya manusia dalam sebuah negara. Pendidikan merupakan suatu hal yang mutlak harus dipenuhi dalam upaya meningkatkan taraf hidup bangsa Indonesia agar tidak sampai tertinggal dengan bangsa lain. Hal ini tercantum dalam Undang-Undang Pendidikan Nasional Nomor 20 Tahun 2003, tentang Sistem Pendidikan Nasional berbunyi sebagai berikut:

Pendidikan adalah usaha sadar dan terencana untuk mewujudkan suasana belajar dan proses pembelajaran agar peserta didik secara aktif mengembangkan potensi dirinya untuk memiliki kekuatan spritual keagamaan, pengendalian diri, kepribadian, kecerdasan, akhlak mulia, serta keterampilan yang diperlukan dirinya, masyarakat, bangsa dan negara (Sisdiknas, 2003).

Dalam membaca Al-Qur'an bermacam-macam jalur yang ditempuh oleh setiap mukmin agar bisa mahir membaca Al-Quran antara lain: melalui 
informal seperti ikut belajar mengaji di mesjid atau musola, privat belajar AlQuran langsung pada kyai/ustad di rumahnya maupun melalui pendidikan formal yaitu pendidikan di sekolah.

Jika anak semenjak dini diajarkan membaca Al-Qur'an mereka akan lebih mudah terbiasa untuk membaca Al-Qur'an, selain itu jika anak telah mampu membaca Al-Qur'an akan ada pengaruh dalam jiwanya, pada umumnya Al-Qur' an mempengaruhi dan meresap pada jiwa kepada siapa saja yang masih bersih dan suci dari berbagai pengaruh luar, maka semakin bersih jiwa seseorang maka semakin besar pula pengaruh yang akan didapatkannya (Hafidzah, 2000).

Salah satu usaha orang tua agar anak-anaknya dapat membaca AlQur'an yaitu dengan memasukkan anaknya kependidikan formal atau non formal seperti Taman Kanak-Kanak (TK) atau Taman Pendidikan Al-Qur'an (TPA), dan dengan sistem pembelajaran yang teratur, menjadikan anak akan lebih terlatih dan terbiasa mempelajari AlQur'an.

Berdasarkan latar belakang masalah inilah maka penelitian ini dilakukan dengan judul "Penerapan Metode Iqro Sebagai Kemampuan Dasar Membaca Al-Quran di TK HIAMA kids.

Beberapa masalah diidentifikasi sebagai berikut: siswa buta sama sekali dengan huruf hijaiyah, siswa belum lancar membaca Al-Qur'an, upaya guru mendapatkan metode baca Al-Quran.

Rumusan masalah dalam penelitian ini adalah Bagaimana
Penerapan Metode Iqro Sebagai Kemampuan Dasar Membaca Al-Quran di TK HIAMA kids?

\section{Pendidikan Berbasis Alquran}

Dalam Islam, anak adalah titipan Allah SWT yang pada akhirnya akan dipertanggung jawabkan kehadapanNya, baik dari segi perkembangan fisik dan spritual, maka yang paling bertanggung jawab dari segala bentuk perkembangan anak adalah orang tua, apakah ia akan menjadi Nasrani, Majusi atau Islam sejati. Seperti Hadis Nabi SAW yang diriwayatkan oleh Abu Hurairah dari Malik, Artinya: Setiap anak dilahirkan dalam keadaan fitrah, maka kedua orangtuanyalah yang menjadikan anak tersebut menjadi Yahudi atau Nasrani.

Salah satu tugas orangtua dan pendidik adalah mengajarkan anak pendidikan agama karena agama dibutuhkan oleh siapapun. Manusia harus memiliki agama agar memperoleh kehidupan yang menyenangkan. Salah satu yang dilakukan oleh orangtua maupun pendidik dalam membiasakan pendidikan agama yaitu mengajarkan anak membaca, baik huruf Al-Quran maupun huruf latin. Dalam mengajarkan membaca Al-Quran pada anak usia dini bukan hal mudah, karena selain memerlukan pengetahuan seorang pendidik juga harus mengetahui metode yang dapat dipakai dalam proses pembelajaran.

Menurut Mentri Agama RI (1991) Metode Iqro adalah cara cepat belajar membaca Al-Quran. Metode Iqro adalah suatu metode membaca Al-Quran 
yang menekankan langsung pada latihan membaca. Adapun buku panduan iqro terdiri dari 6 jilid di mulai dari huruf hikaiyah yang sederhana sampai tahap huruf hijaiyah yang sudah bersambung.

Tujuan dari metode Iqro adalah untuk menyiapkan anak didik menjadi generasi qur' ani. Mencintai Al-Quran merupakan bagian dari rukun Iman yaitu percaya kepada Kitab Allah SWT (Al-Quran) sehingga menjadi pandangan hidup supaya terarah berdasarkan Al-Quran dan Hadist.

Al-Qur'an \{\} , berasal dari
kata qa-ra-a \{\} yang artinya
mengumpulkan dan menghimpun,
qira'ah berarti menghimpun huruf-huruf
dan kata-kata yang satu dengan yang
lainnya ke dalam suatu ucapan yang
tersusun dengan rapi (Al-Qattan, 2001). Al-Qur'an adalah firman ALLAH SWT yang merupakan mukjizat, yang diturunkan kepada nabi dan rasul terakhir dengan perantaraan malaikat Jibril dan tertulis di dalam mushaf yang disampaikan kepada manusia serta diperintahkan membacanya dimulai dengan surat Al-Fatihah dan ditutup dengan surat An-Nas (Husnan, 2009). Dapat disimpulkan bahwa Al-Qur'an adalah firman Allah SWT yang diturunkan kepada nabi Muhammad SAW dengan perantara malaikat Jibril berisi firman Allah SAW untuk umatNya untuk menggapai kebahagian dunia dan akhirat.

Belajar Al-Qur'an dapat dibagi dalam beberapa tingkatan, yaitu: pertama adalah belajar membacanya sampai lancar dan baik, menurut kaidah- kaidah yang berlaku dalam qira'at dan tajwid, kedua yaitu belajar arti dan maksud yang terkandung di dalamnya, dan terakhir yaitu belajar menghafal di luar kepala, sebagaimana yang dikerjakan oleh para sahabat pada masa Rasulullah, hingga masa sekarang.

Membaca Al-Qur'an harus benar-benar diperhatikan panjang pendek huruf yang dibaca, tidak boleh dipercepat bacaannya dan tidak boleh dibaca asal-asalan sehingga tidak salah penafsiran arti atau makna bacaannya.

Beberapa hukum tajwid yang paling sederhana untuk bisa dipelajari sebelum membaca Al-Qur'an adalah:

1) Idzhar ( $\$$ ) artinya jelas. Hurufnya 6, yaitu : \$ Idzhar adalah apabila nun mati atau tanwin bertemu dengan salah satu hurufnya, maka dibacanya harus jelas nunnya.

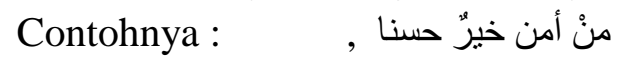

2) Idgham ( ), artinya memasukkan (huruf yang depan kepada huruf yang belakang). Hurufnya ada 6, yaitu : برملون ) Idgham terbagi menjadi dua, yaitu:

a) Idgham bigunnah ( ) artinya: dengan dengung (menahan huruf yang masuk sebanyak 2 harkat). Hurufnya ada 4, yaitu

(يمنو) Idgham bigunnah adalah apabila ada huruf nun mati atau tanwin bertemu dengan salah satu hurufnya, maka dibacanya harus berdengung. Contohnya : من يعمل من نبيّن , خيرِّمن

b) Idgham bilagunnah ( ) artinya : tidak dengan dengung. 
Hurufnya ada 2, yaitu :

Idgham bilagunnah adalah apabila ada nun mati atau tanwin bertemu dengan salah satu hurufnya, maka dibacanya tidak berdengung.

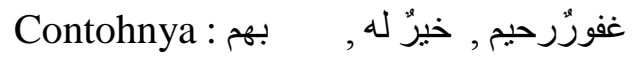

3) Ikhfa ( إ خفاكُ ( artinya samar-samar. (seperti bunyi ng dalam bahasa Indonesia). Hurufnya ada 15, yaitu :

Ikhfa adalah apabila ada nun mati atau tanwin bertemu dengan salah satu hurufnya, maka dibacanya samar-samar. contohnya : , إن كنتم شئق قدير

4) Iqlab ( ), artinya mengganti (mengganti huruf nun ke huruf mim). Hurufnya ada 1, yaitu : Iqlab adalah apabila huruf nun mati atau tanwin bertemu dengan huruf $\mathrm{Ba}^{\prime}$, maka dibacanya balem, contohnya : الأنبيآ؛,

5) Mad ( ) artinya : memanjangkan bacaan, dengan menggunakan 2 harakat. Hurufnya ada tiga, yaitu:

- , - - , - Alif mati sesudah fathah, Ya' mati sesudah kasroh dan Wau mati sesudah domah (AlHafizhah, 2009).

Tujuan mempelajari ilmu tajwid untuk menjaga lidah agar terhindar dari kesalahan dalam membaca Al-Qur'an, dan merupakan dasar membaca AlQur'an yang wajib dikuasai, ini dapat mudah dipelajari dengan metode Iqro.

\section{Metode Iqro}

Metode Iqro' adalah cara mengajarkan al-Qur'an yang mengacu pada pola pendidikan "Child Centered", yaitu memberikan kesempatan yang seluas-luasnya kepada setiap siswa atau santri untuk berkembang secara optimal sesuai kemampuan (Mu'min, 1991).

Metode Iqro' tersusun dalam bentuk buku yang terdiri dari 6 jilid, dan buku iqro' memiliki sifat-sifat sebagai berikut: (LPGTK, 1992).

1) Bacaan langsung

Yaitu tanpa dieja; tidak diperkenalkan terlebih dahulu nama-nama huruf hijaiyah, tanda baca atau harakat, tetapi langsung diajarkan bunyi $\mathrm{A}, \mathrm{Ba}, \mathrm{Ta}$ dan seterusnya.

2) CBSA (Cara Belajar Santri Aktif)

Yang belajar adalah santri, sehingga santri harus didorong untuk aktif dan guru hanya membimbing saja, guru hanya menerangkan pokok pelajarannya saja dan setelah santri jelas dan bisa, maka santri disuruh membaca sendiri bacaan berikutnya dan guru hanya menyimak saja.

3) Privat

Santri dalam belajar membaca $\mathrm{Al}$ Qur'an harus berhadapan langsung dengan gurunya, sehingga santri tahu bagaimana mengucapkan huruf-huruf sesuai dengan kaidah makhroj, dalam hal ini santri disimak satu persatu secara bergantian.

4) Modul

Santri dalam menyelesaikan materi Iqro' tergantung kemampuan dan usahanya sendiri, tidak berdasarkan kemampuan kelas atau rekannya, mereka yang cerdas dan rajin akan cepat selesai, sehingga cepat dan lambatnya menamatkan Iqro' 
tergantung keadaan masing-masing santri, sehingga meskipun mulai bersama-sama, namun kapan selesainya sangat bervariasi, dalam hal ini adanya kartu prestasi Iqro' setiap santri sangat berguna untuk memantau dan mengendalikan kemajuan santri.

5) Asistensi

Jika terpaksa kekurangan tenaga guru, maka bisa menunjuk santri santri terpilih yang sudah sampai jilid 4, 5 dan 6, untuk menjadi asisten penyimak bagi santri yang masih jilid 1, 2 dan 3.

6) Praktis

Tujuan utama pengajaran AlQur'an ini adalah santri bisa membaca Al-Qur'an dengan mudah dan cepat, sehingga hal-hal yang bersifat teoritis (teori ilmu tajwid) diajarkan setelah santri bisa membaca Al-Qur'an dengan baik dan benar, maka buku Iqro' disusun sebagai dan diajarkan secara praktis, langsung menekankan praktek, tanpa mengenalkan istilahistilah ilmu tajwid, jadi langsung diajarkan bagaimana pengucapannya.

7) Sistematis

Disusun secara lengkap dan sempurna serta terencana dengan komposisi huruf yang seimbang, di mulai dari pelajaran yang amat dasar dan sederhana, dengan rangkaian huruf-huruf, sedikit demi sedikit, tahap demi tahap, akhirnya ke tingkat satu kalimat yang bermakna, hanya saja karena prosesnya yang sangat evolusi semuanya menjadi terasa ringan.

8) Variatif

Disusun secara berjilid-jilid terdiri dari 6 jilid dengan sampul warnawarni, sehingga menarik selera untuk saling saling berlomba di dalam mencapai warna-warni jilid berikutnya, di samping untuk menghindari kejenuhan santri.

9) Komunikatif

Ungkapan kata rambu-rambu petunjuk, akrab dengan pembaca sehingga menyenangkan bagi yang mempelajarinya, juga diselingi ungkapan kata dalam bahasa Indonesia yang berkesan, di samping itu lafal-lafalnya penuh dengan irama sehingga enak didengar dan dirasakan.

10) Fleksibel

Buku Iqro' dipelajari oleh anak untuk usia TK sampai mahasiswa serta orang-orang tua (manula), disamping itu, siapa saja yang sudah dapat membaca Al-Qur'an pasti bisa mengajarkannya, bahkan yang baru tamat jilid 2 pun bisa mengajarkan kepada yang baru belajar jilid 1, sehingga bisa menumbuhkan suasana asyik saling mengajar.

Adapun target pencapaian dari tiap-tiap jilid buku iqro' berbeda-beda. Untuk mengetahui kemampuan santri apakah telah menguasai materi pelajaran, maka pada tiap jilid diakhiri dengan EBTA, santri yang cepat 
menguasai materi akan cepat pula dalam menyelesaikan buku Iqro'nya.

Tabel 1: Huruf Hijaiyah dan Cara Pengucapannya
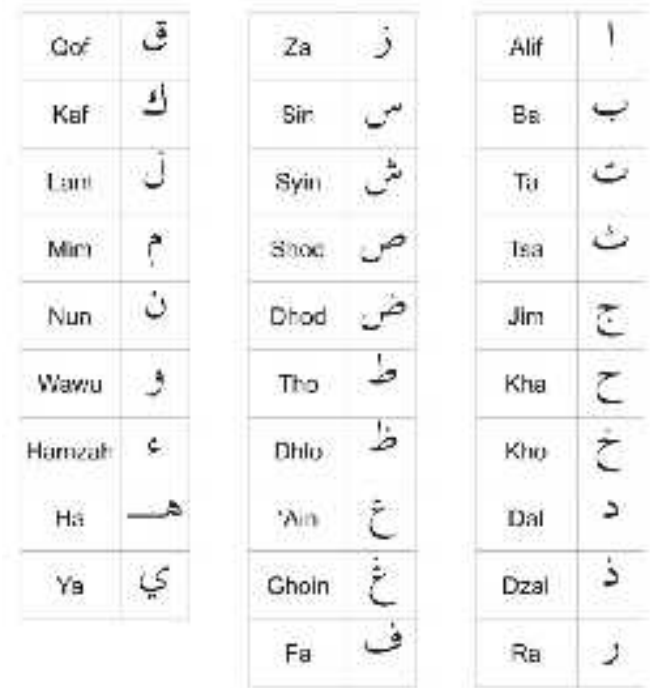

\section{METODE}

Permasalah dalam penelitian ini yang telah dikaji merupakan masalah yang bersifat sosial. Sehingga peneliti memilih menggunakan metode penelitian kualitatif untuk mencari, memperoleh, dan menganalisis data hasil dari observasi yang dilakukan penelitian. Menurut Sugiyono (2011: 8) bahwa metode penelitian kualitatif yaitu metode penelitian naturalistic karena penelitiannya dilakukan pada kondisi yang alamiah (natural setting).

\section{HASIL DAN PEMBAHASAN}

Visi TK HIAMA kids adalah Menciptakan generasi Qur'ani yang cerdas, kreatif, inovatif, dan professional dalam menghadapi tantangan zaman.

Adapun Misi dari TK HIAMA kids adalah:
1. a) Mengimplementasikan nilai-nilai Islam ke dalam lingkungan pembelajar.

2. b) Mengasah dan mengoptimalkan potensi siswa untuk mencapai Multi Intelegensi

3. c) Menciptakan kreativitas siswa sehingga menjadi menjadi asset bangsa yang bermanfaat.

Beranjak dari pemikiran inilah TK HIAMA kid menggunakan metode active learning dengan pembelajaran terpadu dan tuntas, dan suasana belajar yang PAKEM (Proses, Aktif, Komunikatif, Kreatif, Efektif, dan Menyenangkan).

Dari hasil observasi peneliti, TK HIAMA kids memulai pembelajaran pukul 07.30 sd 11.00 setiap Senin sd Jumat.

Senin dan Rabu menggunakan seragam kotak kotak kuning mata pelajarannya Calistung dan Bahasa Inggris, Selasa dan Jumat menggunakan seragam gamis/koko mata pelajarannya Pendidkan Agama Islam dan Bahasa Arab. Sedangkan Rabu kegiatan olahraga materinya olahraga dan moving class creativity. Perencanaan Pembelajaran dibuat setiap Jumat oleh guru berbentuk tabel RKH (Rencana Kegiatan Harian).

Untuk kegiatan membaca Alquran dengan metode Iqro dilakukan Setiap Senin samapai dengan Jumat. Siswa HIAMA kids memulai mata pelajaran 45 menit pertama dengan Murajaah surat pendek juz 30 dan melanjutkan membaca buku Iqro 
Kegiatan pembelajaran HIAMA kids mulai pukul 07.30, para siswa masuk ke dalam kelas dengan meletakan sepatu di rak sepatu. Siswa hanya diantarkan sampai pintu gerbang pagar karena hanya pada awal masuk sekolah ajaran baru para siswa boleh ditunggui oleh orangtua selama 3 hari.

Siswa masuk ke kelas dengan mengucapkan salam dan salim dengan mencium tangan ustadzah lalu meletakan tasnya di belakang kursi tempat duduk mereka. Guru di kelas dipanggil dengan sebutan ustadzah.

Murojaah bersama dan membaca buku Iqro dilakukan pada awal pembelajaran karena umunya sebagain siswa belum pada hadir keseluruhan sehingga sambil menunggu siswa semuanya hadir. Kegiatan awal pembelajaran dimulai dengan murojaah (membaca Al-Quran bersama-sama) didampingi ustadzah mulai dari surat Annas samapi surat Al-Humazah. Kemudian dilanjutkan membaca iqro secara privat oleh guru dengan maju ke depan dengan bimbingan ustdzah.

Sebelum membaca huruf hijaiyah di buku Iqro, ustadzah terlebih dahulu mengenalkan beberapa huruf hijaiyah di papan tulis sekaligus cara membaca dan cara menuliskannya. Setelah ustadzah memberi penjelasan kemudian ustadzah mengarahkan agar para siswa mengambil buku tulis dan buku Iqro dan memberi tugas dengan menyalin buku Iqro ke buku tulis mereka sambil menunggu siswa bergantian membaca buku Iqro. Lalu diabsenlah siswa untuk maju ke depan untuk membawa buku Iqronya dan langsung membacanya. Siswa jika lancar membaca maksimal 3 halaman buku Iqro, Jika tidak lancar hanya 1-2 halaman saja. Setelah membaca iqro ustdzah langsung mengetes hafalan surat pendek dari juzama. Jika sudah selesai, siswa akan kembali ke tempat duduknya lalu melanjutkan menyalin tulisan yang ada di buku Iqro ke buku tulis para siswa. Selanjutnya satu persatu siswa dipanggil lalu membaca buku Iqro dan hafalan surat pendek.

Setelah semuanya sudah selesai membaca dan hafalan surat pendek, ustadzah akan mengarahkan para siswa untuk mengumpulkan buku tulis yang telah mereka salin bacaan iqro untuk dinilai. Semua sudah selesai, lanjut para siswa berkumpul membuat lingkaran lalu duduk bersila di bawah (lantai beralas karpet) lalu membaca AlFatihah dan doa belajar bersama-sama. Kemudian dilanjutkan dengan ice breaking agar pembelajaran lebih semangat dan menyenangkan berupa lagu-lagu dan yel yel TK. Kemudian dilanjutkan dengan mengabsen siswa satu persatu dan menanyakan kabarnya siswa hari ini sehingga siswa bisa bercerita. Setelah semuanya selesai ustadzah kemudian melanjutkan materi yang akan disampaikan.

Media yang digunakan dalam membaca Al-Quran dimulai dengan buku Iqro dan ditambah beberapa media pembelajaran seperti penggunaan papan tulis, poster huruf hijaiyah, dan beberapa permainan huruf hijaiyah berupa puzzle. 
Peneliti melihat ketika siswa maju kedepan untuk membaca buku Iqro secara private atau langsung ke depan ustadzahnya, dapat dilihat ada yang sudah mahir membaca huruf hijaiyah, ada yang belum mahir membaca huruf hijaiyah ataupun ada siswa yang tidak mengetahui huruf hijaiyah maupun ada yang lupa huruf hijaiyah sehingga kadang terbolak balik bacanya.

Siswa dilatih pula menulis huruf hijaiyah dari modul buku yang digunakan di sekolah. Menulis huruf hijaiyah berbeda dengan menulis huruf latin/Indonesia. Menuruf huruf hijaiyah dimulai dari posisi sebelah kanan dan penulisan ada caranya sehingga ustadzah akan mencontohkan di papan tulis.

Dalam pelaksanaan membaca Al-Quran dengan metode buku Iqro dapat dilihat bahwa:

1. Apabila dalam membaca 1 halaman buku Iqro tidak gagap dan tidak terputus-putus serta memakan waktu tidak lebih dari 5 menit maka siswa tersebut mahir membaca iqro

2. Apabila dalam membaca 1 halaman buku Iqro tidak tergagap dan memakan waktu hampir 7 menit. Artinya siswa bisa membaca huruf hijaiyah tapi belum lancar membacanya.

3. Apabila dalam membaca masih tergagap dan terputus-putus serta memakan waktu lebih dari 7 menit. Artinya siswa belum bisa baca huruf hijaiyah.

\section{KESIMPULAN}

Berdasarkan hasi penelitian dan pembahasan yang dilakukan oleh penelit mengenai penerapan penerapan metode Iqro Sebagai Kemampuan Dasar Membaca Al-Quran di TK HIAMA kids sudah dilakukan dengan baik. Penerapannya dilakukan dengan mengenalkan dasar membaca Al-Quran dengan metode Iqro yang dibimbing oleh para ustadzah satu persatu sehingga siswa lebih mudah memahami huruf hijaiyah sehingga lebih mudah membaca Al-Quran.

\section{Saran}

Berdasarkan hasil penelitian, maka beberapa saran yang dapat dikemukakan penulis adalah sebagai berikut: (1) Ustdazh lebih memperhatikan pengucapan lafal huruf hijaiyah yang tepat, karena peneliti masih melihat beberapa siswa mengucapkan "Bismillah" dengan "Besmillah" ketika memulai membaca. (2) Seolah menyiapkan media pembelajaran yang bermanfaat seperti video pembelajaran agar memngetahui detail cara membaca huruf hijaiyah dan juga alat peraga untuk lebih membuat siswa semangat belajarnya. (3) Ustadzah tidak usah terburu buru melanjutkan halaman buku Iqro jika siswa belum mahir dan lancar membaca huruf hijaiyah.

\section{DAFTAR PUSTAKA}

[1] Al Qattan, Manna Khalil. 2001. Studi Ilmu-Ilmu Qur'an, terjemah Mudzakir AS. Bogor: Pustaka Litera Antar Nusa. 
[2] Al-Hafizhah. Ummi Rif'ah Ishaq. 2009. Pedoman Tilawah Al-Qur'an Ilmu Tajwid. Jakarta: Syukur Press, 2009.

[3] Boediono, ed., 2003. Standar Kompetensi Pendidikan Anak Usia Dini Taman Kanak-Kanak dan Raudhatul Athfal. Jakarta: Departemen Pendidikan Nasional.

[4] Departemen Agama RI. 2007. AlQur'anulkarim Terjemahan Perkata. Bandung: Syaamil Al- Qur'an.

[5] Diknas. Undang-Undang Republik Indonesia Nomor 20 Tahun 2003 Tentang Sistem Pendidikan Nasional, Pasal 1, ayat 1.

[6] Hafizah, Muhammad Nur Abduh Hafizah. 2000. Mendidik Anak Bersama Rosullullah. Bandung: al-Bayan.

[7] Husnan, Djaelan, dkk, 2009. Islam Integral Membangun Kepribadian Islami (Jakarta: Fakultas Ilmu Sosial Universitas Negeri Jakarta

[8] Marimba, Ahmad D. 2009. Pengantar Filsafat Pendidikan Islam. Bandung : Al- Maarif.

[9] Materi Penataran Calon Guru dan Pengelola TK/TP al - Qur'an, Petunjuk Mengajar Buku Iqro' dan Metode Pengelolaannya. Lembaga Pembinaan dan Pengembangan TK al - Qur'an BKPRMI

[10] Mentri Agama RI. 1991. Buku Iqro Cara Cepat Belajar Membaca AlQuran. Jakarta: Departemen Agama Pusat

[11] Mu'min, M. CH. 1991. Petunjuk Praktis Mengelola TK Al-Qur'an. Jakarta: PT Fikahati Aneske.
[12] Sugiyono.2011. Metode Penelitian Kuantitatif, Kualitatif, dan $R \& D$. Bandung: Alfabeta.

[13] Zulfitria, 2017. Peranan Pembelajaran Tahfidz Al-Quran Dalam Pendidikan Karakter di Sekolah Dasar. Naturalistic: Jurnal Kajian Penelitian Pendidikan dan Pembelajaran 1, 2 (April 2017): 124-134 